\title{
ONLINE COMMUNICATION WITH CITIZENS. SHOULD LATVIAN PUBLIC INSTITUTIONS LEARN FROM FOREIGN EXPERIENCE?
}

\author{
EDUARDS GAUŠIS ${ }^{1}$
}

University of Latvia (Latvia)

\begin{abstract}
Civic engagement is a core value of democracy that approves legitimacy of democracy itself and decisions made by public institutions. In Latvia, civic engagement rates are decreasing, thus for public institutions it is important to find new ways how to engage citizens in the decision-making process. In the twenty-first century, it means that public institutions should also be present in social media. The objectives of the article are to identify foreign experience how public institutions are using social media for civic engagement and evaluate the reasons for Latvian public institutions to learn from this foreign experience. Accordingly, methods of the research are analysis of scientific publications covering examples about digital democracy, civic engagement and use of social media by public institutions, as well as analysis of data about the Internet and social media usage in Latvia. The study findings suggest that Latvian public institutions are already using social media for one-way communication. Moreover, in Latvia, availability of the Internet and participation rates in social media are above the EU average, thus there is potential to use social media also for two-way communication and foster civic engagement.
\end{abstract}

KEYWORDS: civic engagement, digital democracy, public institutions, social media.

JEL CODES: I28, L86, M15, O31.

DOI:

\section{Introduction}

In democracy, citizens by voting in elections are giving a mandate to public institutions to make decisions on their behalf. Thus, it is important to ensure that decisions made by public institutions agree with the needs and beliefs of citizens. It is the responsibility of institutions to ensure available options for citizens to participate in the decision-making process. The need for such options is obvious, because participation rates in elections are decreasing, thus a mandate given via elections to the public institutions is not representing all the citizens but only those who participated in the elections. Accordingly, the problem studied in this research is lack of civic engagement in the decision-making process. To ensure that the major part of citizens participate in the decision-making process, there is a need for an easy procedure ensuring that citizens could be heard by public institutions not only once in a few years during elections, but also on a daily basis.

Nowadays, the Internet is providing possibilities for communication between citizens and public institutions. In Latvia, public institutions are also represented on social media. Advances of social media are technical possibilities for the two-way communication and fast exchange of information without mediators. However, social media usually is used for one-way communication, representing public institutions to citizens but not encouraging them for a dialogue. The purpose of the research is to analyse foreign experience on how social media is used by public institutions for civic engagement and to evaluate what conditions should be considered seeking to adapt this experience in Latvia. The studied research object is civic engagement

1 Eduards Gaušis - PhD student at the Faculty of Business, Management and Economics, University of Latvia

Scientific interests: civic engagement and use of social media for educational and informative purposes

E-mail: eduards@klubsmaja.lv 
in the age of digital democracy. Technical possibilities of the Web 2.0 ensure that public institutions can be closer to citizens but there is still a need for thoughtful communication strategies how institutions can engage citizens in a dialogue using social media. Therefore, the tasks of the study are: to identify foreign experience on how public institutions are using social media and to investigate if social media can be used by public institutions for civic engagement in Latvia. Accordingly, the research methods are as follows: analysis of scientific publications covering examples about digital democracy, civic engagement and the use of social media by public institutions; analysis of data about the Internet and the social media usage in Latvia. In the article there are emphasized essential aspects collected from the analysed foreign cases demonstrating how public institutions are using social media for two-way communication. Considering the possibilities to learn from this foreign experience, the author analyses and highlights the reasons why social media could be used by Latvian public institutions for civic engagement. Conclusions provide the main findings of the research and give recommendations for future studies on the use of social media for civic engagement in Latvia.

\section{Democracy and civic engagement}

Civic engagement is a core value of democracy not only as a necessary system which enables public institutions to ensure citizens' opinion in the decision-making process, but also as a catalyst that approves legitimacy of democracy itself and the decisions made by public institutions. It is up to citizens to what extent they are ready to participate in democratic processes. They can choose to participate in elections by voting and thus giving their mandate to public institutions to make decisions on their behalf. Moreover, citizens can also seek for more active civic engagement opportunities, such as: participating in political parties, becoming members of nongovernmental organisations, taking part in public consultation processes or providing their opinion about bills and other decisions that public institutions are having on their agenda. It is essential that for the sake of good democracy public institutions are providing citizens with various everyday civic engagement possibilities and are motivating citizens to take part in those activities. In Latvia, citizens' participation in the decision-making process is regulated by the Cabinet Regulation No. 970 "Procedures for the Public Participation in the Development Planning Process" of the Republic of Latvia. It provides wide opportunities for citizens to take part in several stages of the decision-making process and defines that in case of certain "development planning in a field or a sector of policy, or territory" the liable institution is responsible for selecting "the most appropriate types of public participation, promoting efficient, open, inclusive, timely and responsible public involvement in the development of planning process" (Latvijas Vēstnesis, 2013). For example, the Ministry of Justice has a separate section on their home page where citizens can find information about the bills presented on the Ministry's agenda and learn what procedures one should follow to provide his or her input in the decision-making process (Tieslietu ministrija, 2018). Thus, citizens in Latvia have legally developed ways how they can participate in the decision-making process. However, they need to be proactive and informed about the topical bills or should participate in nongovernmental organisations that are representatives of society in a specific area.

At the same time, statistics about the Latvian citizens' participation in the civic engagement activities highlights a situation which could be described as a democratic deficit. In Latvia, similarly to international tendencies, participation rates in elections are decreasing. For the Latvian parliament elections, the participation rate dropped from 71.90 percent in 1995 to 58.90 percent in the latest 2014 elections (CSB, 2016). Participation rates in the municipality elections are decreasing but without a constant trend, as the largest activity was in 2001 with $62.00 \%$ and lowest in 2013 with $46.00 \%$, but in the latest 2017 municipality elections participated 50.39\% of eligible voters (CVK, 2018). Participation rates in the European Parliament elections are also without a constant trend, however showing low participation rates in general. Latvia's citizens have voted in the European Parliament elections three times: in 2004 participated $41.34 \%$ of eligible voters, in 2009 participated $53.70 \%$, and in the latest 2014 elections $-30.24 \%$ of eligible voters. It should be pointed out, that 2009 European Parliament elections were organised at the same time as the Latvian municipality elections (European Parliament, 2014). One of the reasons for low participation rates in the elections often 
is mentioned public disbelief in political parties. At the same time, it is also considered as one of the reasons why citizens themselves are not ready to become members of political parties (Providus, 2017). In Latvia, less than one percent of citizens are members of political parties whereas in the EU the average is $4.70 \%$ (van Biezen, Mair, Poguntke, 2012: 28). Therefore, political parties and the election process in Latvia do not entirely represent all citizens, but only those who participated in the elections or are members of the political parties themselves.

In the day-to-day civic engagement, the great importance is given to nongovernmental organisations that are participating in the advisory boards or from time to time are invited by public institutions to provide their view if some bill is affecting their field of competence. Nevertheless, five percent of the Latvian population participate in nongovernmental organisations (Pārresoru koordinācijas centrs, 2017: 74), thus, nongovernmental organisations only theoretically represent citizens and there is risk that nongovernmental organisations defend only their members' interests. Therefore, there exists a silent majority in Latvia that is not participating in the decision-making process, though the decisions made by public institutions influence their life as well.

\section{Public institutions and social media}

What can be done by public institutions to promote civic engagement and involve more citizens in the decision-making process? Preferably, public institutions should reach citizens in the places where they are residing. In the $21^{\text {st }}$ century it also means to be present in social media. As Manuel Castells points out, it is the sphere where social changes are fostered by companies and nonstate actors, thus "...it is essential for state actors ... to relate to civil society not only around institutional mechanisms and procedures of political representation but in public debates in the global public sphere." (Castells, 2008: 90). Also, E. Bonsón et al. emphasizes the opportunity of engagement that social media can provide: "By forming or joining existing online communities that discuss issues of relevance to local policy, service delivery, and regulation, local governments and their officers will become more informed, responsive, innovative, and citizen-centric" (Bonsón, Torres, Royo, Flores, 2012). If public institutions desire to engage citizens in dialogue and increase their civic engagement, they should be the ones who make the first step. Thus, public institutions should be not only present on social media, but they need to be proactive there and purposefully provide citizens with civic engagement opportunities.

The worldwide encouragement that social media can be used not only for entertainment and communication with friends but also for civic engagement purposes took place in 2008, during the USA election campaign after which also European Parliament for 2009 elections created accounts on several social media sites (Vesnic-Alujevic, 2013). Since then, the use of social media by public institutions has grown remarkably. The European Union here is a good example: considering data available on the European Union social networks search tool, the EU institutions are represented on more than 10 different social media sites and the search tool is providing information about more than 15 different EU institutions and agencies (European Commission, 2018). Latvian public institutions have accounts on social media as well. Among the Latvian ministries the most popular social media is Twitter.com, where all ministries have one or even several accounts, also Facebook.com and the Latvian local social network Draugiem.1v, few ministries also post information on Instagram.com (Ministru kabinets, 2017). Thus, the amount of social media accounts maintained by Latvian public institutions suggests that institutions in Latvia have managed modern communication tools very well. In general, that is true, and Latvia can be an example of how public institutions participate in social media. However, the communication of Latvian public institutions in social media is mostly one-way and top-down, informing about topical events and decisions rather than encouraging citizens for two-way communication and dialogue. Nevertheless, research of international studies suggests that social media have the potential for two-way communication between institutions and citizens, and there are several examples and conclusions that could be also useful for Latvian public institutions. 
Positive aspects of the Internet and Web 2.0 to civic engagement were observed in the study of citizens coproduction in the USA, pointing out that "the advent of social media and web 2.0 interactivity indeed appear to enhance and expand the viability of and capacity for citizen coproduction, not only in traditional citizen-to-government arrangements but also in arrangements whereby the government informs, assists, and enables private actions or whereby citizens assist one another, with IT replacing government as vehicle for collective action" (Linders, 2012: 451). K. Mossberger et al. conducted a study about the use of social media in the 75 largest cities of the USA concluding that social media is used primarily for representation, though evidence about networking elements was present. In the study, researchers concluded that "city officials would like to know more about who is using these new tools, how they are being used, and what is needed to further develop them" (Mossberger, Wu, Crawford, 2013) suggesting that there is observable an interest from content creators to develop thoughtful social media strategies. The study about the use of Web 2.0 and social media tools in the EU local governments concluded that use of social media is not only about communication strategies, but also "about a new approach to governance. The introduction of ICTs without the corresponding changes in leadership, policy, and governance is unlikely to result in a more consultative, participatory, collaborative, and transparent government" (Bonsón, Torres, Royo, Flores, 2012). The study about the social media impact on civic engagement has indicated that in Malaysia "online civic behaviour is present and that social media as a civic communication channel enables citizens to be included in civic participatory activities" adding that government needs to "put citizens at the centre" to build citizens' trust to institutions (Warren, Sulaiman, Jaafar, 2014). From the citizens' perspective, social media as a civic engagement tool can be evaluated positively as their "substantial relative advantage arises with respect to previous generation of e-participation models due to the fact that government makes a first step towards citizens rather than expecting the citizenry to move their content production activity onto the 'official' spaces created for e-participation" (Ferro, Loukis, Charalabidis, Osella, 2013: 366). Thereby, it is important to be aware that citizens are more eager to participate in the decision-making process if those civic engagement activities are not asking from them very much effort and extra steps.

Foreign experience cases often suggest that implementation of social media as a civic engagement tool should be done, firstly, by developing communication strategies. For the USA agencies, there are recognised four input mechanisms that are influencing the decision to adopt social media: "Observations of citizens use of social media; Passive observations of highly innovative departments and agencies; Active interaction with peers; and formal guidelines developed by lead agencies" (Mergel, 2013: 125). G. Lee and Y. H. Kwak with their Open government maturity model is emphasizing that it is important to develop social media communication step-by-step, starting with the first level, where social media is never or seldom used, then continuing with data transparency and providing participation possibilities, later, in the fourth level, offering open collaboration options to citizens. Finally, at the fifth level, citizens can take an action via their computers and smartphones and "openness becomes a norm for government culture and the public engages in government throughout their entire lifetime" (Lee, Kwak, 2012). Overall, the biggest challenge to public institutions is not the use of social media as such, but the comprehension how to use social media purposely and integrate them into the traditional decision-making process.

\section{Learning from foreign experience}

There are foreign examples and academic conclusions in the cases from the USA and the other European Union countries, how and why to use social media for civic engagement. Yet, why should Latvia's public institutions take this information into consideration? At first, the previously discussed civic engagement situation in Latvia is demanding from public institutions to act and engage citizens in dialogue. Social media could be a convenient tool for this purpose as communication in social media is direct, fast and comparatively cheaper than in the traditional mass media. Moreover, technical possibilities of social media ensure several ways how two-way communication can be fulfilled. Secondly, good availability of the Internet increases chances to easy reach Latvian citizens in social media. In 2017, according to the Central Statistical Bureau 
of Latvia, $78.60 \%$ of all Latvian households had access to the Internet (CSB, 2018). In 2017, $60.00 \%$ of people of the Latvian population were participating in social networks, the youth participation rate being even higher $-92.00 \%$, which is in both age categories above the EU average (Eurostat, 2017). Thus, it is obvious that in Latvia a large part of people are available on social media and Latvian public institutions already have their accounts in social media, so the basic conditions for the two-way communication has been set. Now, it is up to public institutions to demonstrate if they can use this opportunity and engage citizens in the dialogue.

Are Latvian public institutions ready to learn from foreign experience how to make the citizens' voice more heard? The good news is that at some level they have been already doing that. Since 2011, Latvia has been participating in the Open Government Partnership which is "multilateral initiative that aims to secure concrete commitments from governments to promote transparency, empower citizens, fight corruption, and harness new technologies to strengthen governance" (Open Government Partnership, 2018). In the framework of this initiative, Latvia has developed three national action plans, the newest one of which was started in November 2017 and will be carried out until June 2019 (Ministru kabinets, 2018). If the commitments of the third action plan are completed, then citizens will have access to an open data portal and civic engagement opportunities in Latvia will be strengthened (Valsts kanceleja, 2017). Although the emphasis on civic engagement strengthening in this action plan is still on civic engagement via nongovernmental organisations rather than individual engagement, successful implementation of the action plan would mark Latvia at the stable second level of the Open Government Maturity Model. To reach the third level, more active use of social media and Web 2.0 tools for civic engagement will be needed and, as G. Lee and Y. H. Kwak are pointing out when describing the third level of their model "It is important ... to build the capability to respond to the public's feedback timely and consistently. This capability requires formal processes, coordination mechanisms, and dedicated government employees responding to public comments" (Lee, Kwak, 2012: 498). In this aspect, Latvia's public institutions still need to develop their communication strategies and skills that could be quite a challenge, although foreign experience suggests that this change of mindset is a difficult task also to public institutions in other countries. Thus, learning from one another could be the good experience how to adopt social media for civic engagement more successfully.

Nevertheless, there is one position where Latvia already has signs of the third level of the Open Government Maturity Model and can be an example to other countries. Since 2011, a nongovernmental organisation "Sabiedrības Līdzdalības Fonds" in Latvia has developed and maintained an online platform for community initiatives - manabalss.lv, where Latvian citizens can propose new bills and vote for them. If some legislation initiative collects ten thousand votes, it is handed to the Latvian parliament for further consideration (Sabiedrības Līdzdalības Fonds, 2018). In 2017, the same organisation started another civic engagement initiative - online platform Parvaipret.lv, where citizens can vote on bills that are on the parliament's agenda and later compare their position with the one of politicians (ParVaiPret.lv, 2017). Those projects are recognised by the Latvian public institutions and are regularly mentioned as a good example how institutions are supporting civic engagement in Latvia, although this initiative came and is maintained by the nongovernmental sector. In any case, this cooperation and support suggest that Latvian public institutions are interested in future development of civic engagement in Latvia, which presuppose that one-day Latvian citizens will be able to have two-way online communication with public institutions as well.

\section{Conclusions}

The use of social media for civic engagement is a topic that has been in the sight of academia almost for ten years, since the time when Web 2.0 became a reality and public institutions started to participate in social networks. Since then, social media has developed and grown its impact on society, as well as the communication strategies of public institutions in social media have evolved. Nevertheless, this topic still should be considered as a new territory where not all the rules have been formed yet, as well as not all possible applications and influences have been identified. Therefore, from an academic perspective, it is important to study the current situation and analyse the possible strategies how social media can be used for civic engagement. 
From the public institutions' perspective, it is important to be there where citizens are and communicate with them in a contemporary manner. Studies of foreign experience suggest that public institutions are interested in the reasonable use of social media and there are success stories how social media can be used for civic engagement. Furthermore, there are designed and tested models, how institutions can foster the use of Web 2.0 technologies for civic engagement. Thereby, Latvian public institutions should learn from foreign experience, especially from the other European Union countries and the USA where organisation of democratic processes and civic engagement opportunities are similar as in Latvia. At the same time, it is possible to identify several common challenges that public institutions in the USA and in the European Union have when they are communicating with citizens online. For example, the ability to change communication style from one-way to two-way communication and ensure competent and fast response to citizens online. As the biggest challenge stands out the need for structural changes, i.e., how an institution is processing information that is gathered in social media and how this information can be used in the decision-making process.

Those challenges are also topical for Latvian public institutions where social media have been already adapted as a tool for one-way communication with society and the first steps in the open government environment have been taken as well. Therefore, foreign experience could be useful in fostering the processes and gaining as many benefits from social media as possible. As the Latvian civic engagement rates are decreasing there is a need for public institutions to take actions and develop new ways how to engage citizens in the democratic decision-making process. Therefore, more reasonable use of social media is needed, and Latvia has good potential to use social media for civic engagement by public institutions, considering that availability of the Internet and participation rates in social media are above the EU average. Taking into account foreign experience, Latvian public institutions step-by-step should develop the two-way communication in social media, starting with short campaigns about topical subjects that would little by little accustom citizens to the probability that institutions are interested in citizens' opinion and their voice is considered in the decision-making process. In addition, Latvian public institutions should also highlight our own digital democracy success stories, ensuring that citizens are informed about such community initiatives platform as manabalss.lv and public institutions are taking it seriously as a valuable civic engagement tool. However, additional studies of the current situation in Latvia are needed to ensure that the potential to use social media for civic engagement is fulfilled. It is important to understand what are the best communication practices that can be used in communication with Latvian citizens online, as well as what steps should be taken by Latvian public institutions to integrate social media in the existing decision-making process.

\section{References}

Bonsón, E., Torres, L., Royo, S., Flores, F. (2012). Local E-Government 2.0: Social Media and Corporate Transparency in Municipalities. Government Information Quarterly, Vol. 29(2), p. 123-132.

Castells, M. (2008). The New Public Sphere: Global Civil Society, Communication Networks, and Global Governance. The ANNALS of the American Academy of Political and Social Science, Vol. 616(1), p. 78-93.

CSB. (2018). Access to a Computer/the Internet by Households. Available at: http://data.csb.gov.lv/pxweb/en/zin/ zin_datoriz_01ikt_datori_01_MS/ITM0010.px/table/tableViewLayout2/?rxid=cdcb978c-22b0-416a-aaccaa $\overline{650} \mathrm{~d} 3 \mathrm{e} 2 \mathrm{ce} 0$.

CSB. (2016). Politiskā dzìve un religíija. Available at: http://www.csb.gov.lv/statistikas-temas/politiska-dzive-un-religija-galvenie-raditaji-30375.html.

CVK. (2018). Pašvaldību vēlēšanas. Available at: https://www.cvk.lv/pub/public/27484.html.

European Commission. (2018). Social Networks. Available at: https://europa.eu/european-union/contact/social-networks_en.

European Parliament. (2014). Turnout. Available at: http://www.europarl.europa.eu/elections2014-results/en/turnout.html

Eurostat. (2017). Database: Science, Technology, Digital Society - Digital Economy and Society - ICT Usage in Households and by Individuals - Internet Use. Available at: http://ec.europa.eu/eurostat/data/database.

Ferro, E., Loukis, N. E., Charalabidis, Y., Osella, M. (2013). Policy Making 2.0: From Theory to Practice. Government Information Quarterly, Vol. 30(4), p. 359-368.

Latvijas Vēstnesis. (2013). Sabiedrības līdzdalības kārtība attīstības plānošanas procesāa. Available at: https://likumi. lv/doc.php?id=197033. 
Lee, G., Kwak, Y. H. (2012). An Open Government Maturity Model for Social Media-Based Public Engagement. Government Information Quarterly, Vol. 29(4), p. 492-503.

Linders, D. (2012). From E-Government to We-Government: Defining a Typology for Citizen Coproduction in the Age of Social Media. Government Information Quarterly, Vol. 29(4), p. 446-454.

Mergel, I. (2013). Social Media Adoption and Resulting Tactics in the U.S. Federal Government. Government Information Quarterly, Vol. 30(4), p. 123-130.

Ministru kabinets. (2018). Atvērtā pārvaldība. Available at: https://www.mk.gov.lv/lv/content/atverta-parvaldiba.

Ministru kabinets. (2017). Ministrijas sociālajos medijos. Available at: http://www.mk.gov.lv/sites/default/files/komunikacijas_files/ministriju_soctikli_02_2017.pdf.

Mossberger, K., Wu, Y., Crawford, J. (2013). Connecting Citizens and Local Governments? Social Media and Interactivity in Major U.S. Cities. Government Information Quarterly, Vol. 30(4), p. 351-358.

Open Government Partnership. (2018). Latvia. Available at: https://www.opengovpartnership.org/countries/latvia.

ParVaiPret.lv. (2017). Par vai pret. Available at: https://parvaipret.lv/bills.

Pārresoru koordinācijas centrs. (2017). Nacionālā ttīstības plāna 2014.-2020. gadam un Latvijas ilgtspējīgas attīstības stratēgijas līdz 2030. gadam īstenošanas uzraudzības ziņojums. Available at: https://www.pkc.gov.lv/lv/valsts-attistibas-planosana/nacionalais-attistibas-plans/nap2020-merki-un-istenosana.

Providus. (2017). Politiskās partijas 21.gadsimtā: domnīcas Providus organizētā foruma ideju apkopojums. Available at: http://providus.lv/article_files/3283/original/Partijas21apkopojumsProvidus.pdf?1483956590.

Sabiedrības Līdzdalības Fonds. (2018). Par ManaBalss.lv. Available at: https://manabalss.lv/pages/par-manabalss-lv.

Tieslietu ministrija. (2018). Tiesību akti. Available at: https://www.tm.gov.lv/lv/sabiedribas-lidzdaliba/diskusiju-dokumenti/tiesibu-akti

Warren, A. M., Sulaiman, A., Jaafar, N. I. (2014). Social Media Effects on Fostering Online Civic Engagement and Building Citizen Trust and Trust in Institutions. Government Information Quarterly, Vol. 31(2),pp. $291-301$.

Valsts kanceleja. (2017). Latvijas trešais nacionālais atvērtās pārvaldības rīcības plāns. Available at: https://www. mk.gov.lv/sites/default/files/editor/atvertas-parvaldibas-plans2017_1.pdf.

Van Biezen, I., Mair, P., Poguntke, T. (2012). Going, Going,... Gone? The Decline of Party Membership in Contemporary Europe. European Journal of Political Research, Vol. 51, p. 24-56.

Vesnic-Alujevic, L. (2013). Members of the European Parliament Online: The Use of Social Media in Political Marketing. Available at: http://www.martenscentre.eu/sites/default/files/publication-files/political-marketing-and-socialmedia.pdf.

\title{
VIRTUALI KOMUNIKACIJA SU PILIEČIAIS. AR LATVIJOS VIEŠOSIOS INSTITUCIJOS TURÉTU MOKYTIS IŠ UŽSIENIO ŠALIŲ PATIRTIES?
}

\author{
EDUARDS GAUŠIS \\ Latvijos universitetas (Latvija)
}

\section{Santrauka}

Pilietinis dalyvavimas yra pagrindinė demokratijos vertybè, kuri svarbi ne tik kaip sistema, parodanti, kaip viešosios institucijos užtikrina piliečių nuomonę sprendimų prièmimo procese, bet ir kaip katalizatorius, kuris patvirtina pačios demokratijos teisètumą ir viešųų institucijų priimtus sprendimus. Latvijoje piliečių dalyvavimo rodikliai mažèja, taigi viešosioms institucijoms svarbu atrasti naujų būdų, kaip įtraukti piliečius ị sprendimų prièmimo procesus.

Kaip viešosios institucijos galètų skatinti piliečių dalyvavimą ir jų ịtraukimą ị sprendimų prièmimo procesą? Pageidautina, kad jos pasiektų piliečius jų gyvenamosiose vietose. XXI amžiuje tai reiškia, kad būtina sudaryti galimybę naudotis socialine žiniasklaida. Socialinès žiniasklaidos esmė - techninès dvišalès ko- 
munikacijos galimybės ir greiti informacijos mainai be tarpininkų. Tačiau socialinè žiniasklaida dažniausia pasitelkiama vienakrypčiam bendravimui, t. y. idejjų sklaidai, neskatinant dialogo.

Straipsnyje nagrinėjama užsienio patirtis, kaip socialinę žiniasklaidą viešosios institucijos naudoja pilietinei veiklai, įvertinta, ị ką reikètų atsižvelgti pritaikant šią patirtį Latvijoje. Užsienio patirties analizè patvirtina, kad viešosios institucijos yra suinteresuotos sąmoningu socialinès žiniasklaidos naudojimu, pristatytos sẻkmès istorijos, kaip socialinè žiniasklaida gali būti naudojama pilietinei veiklai skatinti. Kartu galima pripažinti keletą bendrų problemų, su kuriomis susiduria viešosios institucijos JAV ir Europos Sajungoje, bendraujama su piliečiais internete. Pavyzdžiui, būtina keisti komunikacijos stilių, siekiant grįžtamojo ryšio, reikia struktūrinių pokyčių, kaip įstaiga tvarko informaciją, kuri renkama socialinėje žiniasklaidoje, kaip šią informaciją galima panaudoti priimant sprendimus. Ši tema turètų būti traktuojama kaip nauja neištirta komunikacijos tema, nes neaprašytos procedūros ir nenumatytos piliečių dalyvavimo sprendimų prièmimo procesuose rezultatai. Todèl akademiniu požiūriu svarbu ištirti dabartinę situaciją ir išanalizuoti galimas strategijas, kaip galima panaudoti socialinę žiniasklaidą įtraukiant piliečius ị sprendimų prièmimo procesą. Viešosios institucijos turètų ịtraukti piliečius ị sprendimų priemimą, bendrauti su jais taikydamos šiuolaikines technologijas. Tyrimo išvados rodo, kad Latvijos viešosios ịstaigos jau naudoja socialinę žiniasklaidą idejų sklaidai, interneto prieinamumas ir dalyvavimo jame rodikliai socialinėje žiniasklaidoje yra didesni už ES vidurkị, todèl galima naudotis socialine žiniasklaida, siekiant skatinti abipusị bendravimą ir pilietinị dalyvavimą. Vis dèlto reikia papildomų tyrimų apie dabartinę padètị Latvijoje, siekiant užtikrinti abipusi bendradarbiavimą.

PAGRINDINIAI ŽODŽIAI: pilietinis dalyvavimas, skaitmeninė demokratija, valstybinès institucijos, socialinè žiniasklaida

JEL KLASIFIKACIJA: I28, L86, M15, O31 